\title{
Physiological changes during the growth and development of litchi fruit (Litchi chinensis Sonn.) grown in Vietnam
}

\author{
Le Van Trong ${ }^{1}$, Nguyen Nhu Khanh ${ }^{2}$, Le Thi Huyen ${ }^{1}$, Ha Thi Phuong ${ }^{3}$, Vu Thi Thu Hien ${ }^{4}$
}

\begin{abstract}
Some of the changes in physiological indicators during the growth and development of litchi fruit grown in Vietnam were studied. The length and diameter of litchi fruits reached their maximum value at 10 weeks after anthesis. The content of chlorophyll in litchi peel reached its highest value at 6 weeks and decreased rapidly. The content of carotenoids was low in fruit formation and then increased rapidly until fruit ripening. The vitamin $\mathrm{C}$ content and reducing sugar content increased continuously and reached a maximum at 10 weeks and then decreased slightly. The starch content and lipid content reached a maximum when the fruit was 8 weeks, the total organic acid content reached a maximum when the fruit was 9 weeks and then gradually decreased. The protein content decreased from fruit formation until fruit ripening. Based on these results, we found that the litchi fruit should be harvested at 10 weeks after anthesis to ensure the nutritional value of the fruit during storage.
\end{abstract}

Index terms: litchi fruit, physiological indicators, ripening.

\section{Mudanças fisiológicas durante o crescimento e o desenvolvimento da fruta lichia (Litchi chinensis Sonn.) cultivada no Vietnã}

\begin{abstract}
Corresponding author: levantrong@hdu.edu.vn

Received: May 24, 2020 Accepted: September 17, 2020

Copyright: All the contents of this journal, except where otherwise noted, is licensed under a Creative Commons Attribution License.
\end{abstract}

(cc) $\mathrm{EY}$

\begin{abstract}
Resumo - Algumas das mudanças nos indicadores fisiológicos durante o crescimento e desenvolvimento da fruta lichia, cultivada no Vietnã, foram estudadas. O comprimento e o diâmetro dos frutos da lichia atingiram seus valores máximos 10 semanas após a antese. $\mathrm{O}$ conteúdo de clorofila na casca de lichia atingiu seu valor mais alto em 6 semanas e diminuiu rapidamente. O conteúdo de carotenoides foi baixo na formação dos frutos e aumentou rapidamente até o amadurecimento dos frutos. $\mathrm{O}$ teor de vitamina $\mathrm{C}$ e o teor de açúcar redutor aumentaram continuamente e atingiram um máximo em 10 semanas e depois diminuíram ligeiramente. $\mathrm{O}$ teor de amido e de lipídios atingiu o máximo quando a fruta tinha 8 semanas, e o teor de ácido orgânico total atingiu o máximo quando a fruta tinha 9 semanas e depois diminuiu gradativamente. $O$ teor de proteína diminuiu desde a formação dos frutos até a sua maturação. Com base nesses resultados, verifica-se que a lichia deve ser colhida 10 semanas após a antese para garantir o valor nutricional da fruta durante o armazenamento.
\end{abstract}

Termos para indexação: lichia, indicadores fisiológicos, maturação.

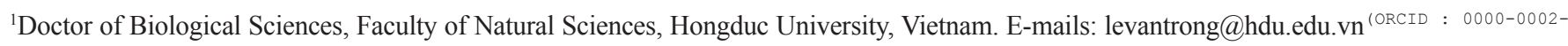
9900-4954); lethihuyentn@hdu.edu.vn(ORCID : 0000-0003-0474-3015)

${ }^{2}$ Professor of Biological Sciences, Faculty of Biology, Hanoi National University of Education, Vietnam. E-mail: nguyennhukhanhsltv@gmail.

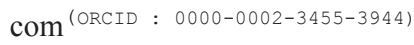

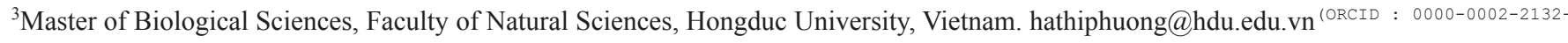
1538)

${ }^{4}$ Master of Biological Sciences, Faculty of Agriculture Forestry and Fisheries, Hongduc University, Vietnam. E-mail: vuthithuhien@hdu.edu. $\mathrm{vn}^{\text {(ORCID : } 0000-0001-5036-4337)}$
} 


\section{Introduction}

Litchi (Litchi chinensis Sonn.) is a species of the Sapindaceae family (MARBOH et al., 2017), which is a major fruit tree in tropical and subtropical regions. The origins of litchis are thought to be in southern China, possibly in northern Vietnam and the Malay Peninsula (MENZEL, 2003). Litchi has grown in many countries around the world with high and stable yields. According to statistics, the countries with the largest production of litchi are China, Taiwan, Vietnam, Thailand, India, Bangladesh, Nepal and South Africa (SINGH et al., 2012). Commercial litchi production in the world has rapidly expanded over the years due to the increasing demand from the European market (HUANG et al., 2005). Litchi trees are suitable for the climatic conditions in the warm subtropics and the tropics with cool dry winters and wet summers (MENZEL et al., 1988). Litchi fruits are small in size, when ripe, have different colors depending on the variety (MENZEL, 2003). Litchi flesh is white and has a dark brown seed inside. Litchi fruit after harvest has a relatively short shelf life. If not well preserved, the peel turns brown, losing its characteristic red color, reducing the commercial value of the fruit. When the brown color of the fruit appears, the quality decreases (CRONJE, 2008), which is important for preserving the litchi fruit to ensure its good condition (HUANG et al., 2005). Therefore, research on the physiological changes of fruit during maturation is one of the main studies.

Vietnam is one of the largest litchi exporters in the world, with many varieties growing and bringing significant economic value. Because of the economic benefits of litchi, growers have invested in litchi cultivation as well as fruit production in many provinces and cities, so the product has increased nationwide. During production and processing, the steps for harvesting and preserving fruit are important to ensure the quality of the fruit and can have a direct impact on consumers. However, the harvesting and preservation of litchi in Vietnam have not had a scientific basis but are based on the experience of gardeners, which makes the majority of litchis in the market not yet ensure quality, affecting the health of consumers. Therefore, we conducted fruit sampling, analyzing the physiological indicators of litchi from formation to fruit ripening. Thereby finding the physiological ripening time of the fruit to help consumers use and preserve the litchi better.

\section{Materials and methods}

Thieu litchi was harvested in Thanhha District, Haiduong Province, Vietnam $\left(20^{\circ} 56^{\prime} 12^{\prime \prime} \mathrm{N}\right.$ and $\left.106^{\circ} 23^{\prime} 18^{\prime \prime} \mathrm{E}\right)$. Physiological indicators were analyzed at the Plant Laboratory, Hongduc University, Vietnam and the Department of Plant Physiology and Application, Hanoi National University of Education, Vietnam.

Samples were collected according to the mixed sampling method. At each stage of the study, we collected samples from twenty trees: 10 fruits per tree. When the fruit had just formed, we proceeded to mark the fruit on the experimental plants. At 2 weeks after anthesis, collections were started and performed every week.

Determination of length and diameter fruit: The length and diameter of the fruit were measured by Panme caliper and accurate to $\mathrm{mm}$.

Determination of pigment content in the peel by the spectral method (MA et al., 2013): Chlorophyll content was calculated by the formulae: $\mathrm{C}_{\mathrm{a}}(\mathrm{mg} / \mathrm{L})=9.784 \mathrm{x}$ $\mathrm{E}_{662}-0.990 \times \mathrm{E}_{644^{\circ}} \mathrm{C}_{\mathrm{b}}(\mathrm{mg} / \mathrm{L})=21.426 \times \mathrm{E}_{644^{-}}-4.650 \mathrm{x}$ $\mathrm{E}_{662 .}$. Carotenoids content was calculated by the formula: $\mathrm{C}_{\text {carotenoids }}(\mathrm{mg} / \mathrm{L})=4.695 \times \mathrm{E}_{440.5}-0.268 \times \mathrm{C}_{(\mathrm{a}+\mathrm{b})}$. Then the pigment content per $1 \mathrm{~g}$ of fresh fruit peel was calculated by the formula: ${ }_{A}=\frac{C \times V}{P \times 100}$ Where: $\mathrm{E}_{662}, \mathrm{E}_{644}$ and $\mathrm{E}_{440.5}$ are the results of measuring chlorophyll color at wavelengths of $662 \mathrm{~nm}, 644 \mathrm{~nm}$ and $440.5 \mathrm{~nm} ; C_{a^{\prime}} C_{b^{\prime}} C_{a+b^{\prime}} \mathrm{C}_{c}$ are respectively chlorophyll content $a, b, a+b$ and carotenoids; $A$ is the content of the pigment in $1 \mathrm{~g}$ of fresh fruit peel; $V$ is the volume of pigment extract $(10 \mathrm{~mL}) ; P$ is the sample mass $(\mathrm{g})$.

Determination of reducing sugar content, starch by Bertrand method (MUI 2001):Reducing sugar content was calculated by the formula: $x=\frac{a \times V_{1} \times 100}{V \times b \times 1000}$

The starch content is calculated by the formula: $\mathrm{Y}=\frac{a \times V_{1} \times 100 \times 0.9}{V_{2} \times b} \quad$ Where: $X$ is the reducing sugar content $(\%) ; Y$ is the content of starch (\%); $a$ is the weight (mg) of glucose obtained; $b$ is the weight of the analyzed sample $(\mathrm{g}) ; V$ is the volume of the diluted sample solution $(\mathrm{mL})$; $V$ is the volume of the analyzed sample solution $(\mathrm{mL}) ; V_{2}$ is the volume of diluted sample solution $(\mathrm{mL}) ; 100$ is the conversion factor to $\% ; 1000$ is the coefficient converting $\mathrm{g}$ to $\mathrm{mg} ; 0.9$ is the coefficient of converting glucose into starch.

Determination of total organic acid content (CHAU et al., 1998): Total organic acid content was calculated by the formula: $x=\frac{a \times V_{1} \times 100}{V_{2} \times P}$ Where: $X$ is the amount of total organic acid present in the extract; $P$ is the amount of analytical sample (g); $V_{l}$ is the total volume of extract $(\mathrm{mL}) ; V_{2}$ is the volume to be titrated $(\mathrm{mL}) ; a$ is the amount of $0.1 \mathrm{~N} \mathrm{NaOH}$ titration $(\mathrm{mL})$.

Determination of vitamin $\mathrm{C}$ content by titration method (ARYA et al., 2000): Vitamin C content was calculated by the formula: $x=\frac{V \times V_{1} \times 0.00088 \times 100}{V_{2} \times P}$ Where: $X$ is the content of vitamin $\mathrm{C}$ in the materials (\%); $V$ is the volume 
of diluted sample solution $(\mathrm{mL}) ; V_{1}$ is the volume of $0.01 \mathrm{~N}$ $\mathrm{I}_{2}$ solution $(\mathrm{mL}) ; V_{2}$ is the volume of analyzed solution $(\mathrm{mL}) ; P$ is the weight of the sample $(\mathrm{g}) ; 0.00088$ is the weight $(\mathrm{g})$ of vitamin $\mathrm{C}$ which was equivalent to $1 \mathrm{~mL}$ of $0.01 \mathrm{~N} \mathrm{I}_{2}$

Determination of protein content by Microkjeldahl method (CHAU et al., 1998): The amount of protein was calculated by the formula: $x=\frac{V \times v_{a} \times 0.142 \times 5.595 \times 100}{v_{c} \times g}$ Where: $\mathrm{X}$ is the protein content $(\%) ; \mathrm{V}_{\mathrm{a}}$ : 1s the volume of $\mathrm{H}_{2} \mathrm{SO}_{4}$ $0.01 \mathrm{~N}$ used to titrate $\mathrm{BO}_{2}^{-} ; V$ is the total volume of enzyme extract $(\mathrm{ml}) ; V_{c}$ : is the volume of $\mathrm{NH}_{3}$ in the analytical extract $(\mathrm{mL}) ; g$ is the weight of the sample $(\mathrm{g}) ; 0,142$ : $\mathrm{mg} \mathrm{N}$ is equivalent to $1 \mathrm{ml} \mathrm{H}_{2} \mathrm{SO}_{4} 0.01 \mathrm{~N}$; 5.595 : is the conversion factor to indicate the result of protein; 100 is the conversion factor to indicate the result in $\%$.

Determination of lipid content by Soxhlet method (CHAU et al., 1998): The lipid content was calculated by the formula: $x=\frac{(a-b) \times 100}{V}$ Where: $X$ is the lipid content (\%); $a$ is the volume of dry sample pack (g); $b$ is the volume of lipid-extracted dry sample pack $(\mathrm{g}) ; V$ is the total volume of dry sample for analysis (g).

Data analysis: All experiments were conducted three times independently. The results are expressed as mean values and standard deviation (SD). The results were subjected to analysis of variance. Data were compared according to Tukey's test using IRRISTAT software (version 5.0) for Windows computers.

\section{Results and discussion}

The length and diameter of the fruit increased according to the growth and development of the fruit (Figure 1). From the period of 2 weeks to 11 weeks after anthesis, the length of fruit increased from $11.63 \mathrm{~mm}$ to $38.22 \mathrm{~mm}$, while the diameter of fruit increased from 5.31 $\mathrm{mm}$ to $37.02 \mathrm{~mm}$ (Table 1). In particular, a sharp increase in fruit size was observed during the period from 2 weeks to 8 weeks. From 9 to 10 weeks, the fruit reached the maximum value of the cultivar in the study condition. At the time of 10 weeks, the length of the fruit reached 38.17 $\mathrm{mm}$ and the diameter reached $36.81 \mathrm{~mm}$. The results of this study showed that at 10 weeks after anthesis, litchi fruit size increased very slowly and remained almost unchanged (Figure 2).

At 2 weeks after anthesis, the content of chlorophyll in litchi peel was low, the content of chlorophyll $a$ was $0.013 \mathrm{mg} / \mathrm{g}$ fresh peel, chlorophyll $b$ was $0.033 \mathrm{mg} / \mathrm{g}$ fresh peel. From 2 to 6 weeks, the content of chlorophyll $a$ and chlorophyll $b$ increased rapidly and reached the highest value at 6 weeks (Chlorophyll $a$ was $0.179 \mathrm{mg} / \mathrm{g}$ fresh peel, chlorophyll $b$ was $0.195 \mathrm{mg} / \mathrm{g}$ fresh peel). After 6 weeks, the content of chlorophyll gradually decreased and decreased rapidly to 11 weeks, this is because fruits begin to move to the stage of ripening, decomposed chlorophyll pigment and carotenoid pigment were synthesized. During litchi coloration, a visible degreening process associated with chlorophyll degradation was noticed (WANG et al., 2005; LAI et al., 2015). This result is consistent with several studies describing that chlorophyll breakdown is associated with the maturity of some kinds of fruit (DU et al., 2014).

During the first weeks of litchi fruit development, low carotenoid content reached $0.006 \mathrm{mg} / \mathrm{g}$ fresh peel at 2 weeks. From 2 to 6 weeks, the content of carotenoids increased slowly, then increase rapidly according to the ripening of the fruit. At 11 weeks, litchi fruit was rich in carotenoid compounds, the content of carotenoids reached $0.728 \mathrm{mg} / \mathrm{g}$ fresh peel. At an early stage, the fruit is primarily green because of the large amount of chlorophyll that obscures the carotenoids, when entering the ripening process, the yellow color of carotenoids appears more due to chlorophyll breakdown (CHAROENCHONGSUK et al., 2015).

Litchi fruit contains large amounts of sugar such as sucrose, fructose and glucose (JIANG et al., 2006), which vary in proportion between varieties (WANG et al., 2006; YANG et al., 2013). The content of reducing sugar in the early period of litchi fruit was relatively low, reached $2.138 \%$ at 2 weeks (Table 2). From 2 to 8 weeks, the content of reducing sugar increased slowly and reached $5.756 \%$ when the fruit was 8 weeks. In the fruit period from 8 to 10 weeks, the content of reducing sugar increased rapidly and reached $14.237 \%$ when the fruit was at 10 weeks. These research results are consistent with the research on total sugar which increases rapidly in the later stages of fruit development (PATEL et al., 2013). At 11 weeks, the content of reducing sugar decreased to $13.907 \%$ so the quality of the fruit decreased.

When the fruit has just formed, low starch content only reached $0.524 \%$ ( 2 weeks after anthesis). The highest starch content was $1.304 \%$ at 8 weeks (Table 2). After 8 weeks, the content of starch in the fruit decreased, this result is consistent with the data Yashoda et al. (2005) on the reduction of starch content in the ripe fruit. When the fruit is ripening, starch and sucrose are converted to glucose, which is the main substrate utilized in respiration (WILLS et al., 1998). Many studies have shown that the respiratory rate of fruit increases sharply during ripening, so starch may have been used more in the respiratory tract (ABU-BAKR et al., 2010; EVELLYN et al., 2012).

The organic acids in fruit are essential for aerobic exchange and make an important contribution to the quality and acidity of the fruit (VALLARINO et al., 2019). When the fruit started its formation, the accumulation of large organic matter amounted to $48.598 \mathrm{mg} / 100 \mathrm{~g}$ fresh weight at 2 weeks. The total organic acid content increased gradually and reached its highest value at 9 weeks. During the litchi fruit period from 9 to 11 weeks after anthesis, organic acid content decreased due to organic acid used in respiration to provide energy for starch synthesis 
processes. On the other hand, energy is needed for the biosynthesis of fruit-specific ripening substances such as enzymes for hydrolysis, esters to create an aroma for fruit in the ripening period and synthesis of sugar to create sweetness for fruits, resulting in a decrease in total acid content (PRASANNA et al., 2007).

The content of vitamin $\mathrm{C}$ from 2 to 10 weeks increased rapidly (Figure 3B). This is a period of strong fruit flesh development and the accumulation of vitamin $\mathrm{C}$ along with other nutrients in the fruit. At 10 weeks, vitamin C content reached $58.667 \mathrm{mg} / 100 \mathrm{~g}$ fresh weight and then vitamin $\mathrm{C}$ content decreased. This result may be related to the activity of certain groups of enzymes involved in ascorbic acid degradation such as ascorbate oxidase, phenolase, cytochrome oxidase, ascorbate peroxidase. Especially, unlike the other antioxidant enzymes, the ascorbate peroxidase activity in the pulp increased continuously during ripening, this is the result shown in the study by Evellyn et al. (2012)
The results of the data in Table 3 show that the content of protein in litchi fruit has a relatively high content from 2 weeks and decreased sharply in the period from 2 to 11 weeks (from $7.238 \%$ to only $3.574 \%$ ). Changes in the protein content indicate a change in metabolic activities during the development of the fruit. The protein content of the fruit decreased during growth and development because the protein in fruit mainly act as enzymes rather than reserves (WILLS et al., 1998).

Lipid content in litchi fruit had a relatively high content at 2 weeks (reached 3.652\%), then increased according to the growth of the fruit and reached the highest value at 8 weeks $(5.537 \%)$. After 8 weeks, the content of lipids in the fruit decreased (Figure 4). At 11 weeks, lipid content reached $3.107 \%$. The decrease in lipids is due to the strong metabolism in the fruit, under the action of lipase enzyme, lipids are hydrolyzed to provide materials and energy for respiration. This is the physiological process that takes place mainly when the fruit enters the ripening stage (WILLS et al., 1998).

Table 1. Length and diameter of litchi fruit and pigment contents in litchi peel

\begin{tabular}{cccccc}
\hline Age of fruit & $\begin{array}{c}\text { Length } \\
(\mathrm{mm})\end{array}$ & $\begin{array}{c}\text { Diameter } \\
(\mathrm{mm})\end{array}$ & $\begin{array}{c}\text { Chlorophyll a } \\
(\mathrm{mg} / \mathrm{g} \text { fresh peel })\end{array}$ & $\begin{array}{c}\text { Chlorophyll } b \\
(\mathrm{mg} / \mathrm{g} \text { fresh peel })\end{array}$ & $\begin{array}{c}\text { Carotenoids } \\
(\mathrm{mg} / \mathrm{g} \text { fresh peel })\end{array}$ \\
\hline 2 weeks & $11.63^{\mathrm{d}} \pm 0.001$ & $5.31^{\mathrm{d}} \pm 0.001$ & $0.013^{\mathrm{b}} \pm 0.001$ & $0.033^{\mathrm{b}} \pm 0.002$ & $0.006^{\mathrm{c}} \pm 0.002$ \\
4 weeks & $19.11^{\mathrm{c}} \pm 0.007$ & $12.52^{\mathrm{c}} \pm 0.042$ & $0.059^{\mathrm{b}} \pm 0.001$ & $0.061^{\mathrm{b}} \pm 0.001$ & $0.019^{\mathrm{c}} \pm 0.001$ \\
6 weeks & $25.12^{\mathrm{b}} \pm 0.040$ & $18.10^{\mathrm{c}} \pm 0.021$ & $0.179^{\mathrm{a}} \pm 0.001$ & $0.195^{\mathrm{a}} \pm 0.002$ & $0.031^{\mathrm{c}} \pm 0.002$ \\
8 weeks & $36.02^{\mathrm{a}} \pm 0.025$ & $26.60^{\mathrm{b}} \pm 0.035$ & $0.147^{\mathrm{a}} \pm 0.001$ & $0.167^{\mathrm{a}} \pm 0.005$ & $0.119^{\mathrm{b}} \pm 0.004$ \\
9 weeks & $38.14^{\mathrm{a}} \pm 0.070$ & $35.24^{\mathrm{a}} \pm 0.082$ & $0.128^{\mathrm{a}} \pm 0.002$ & $0.139^{\mathrm{a}} \pm 0.005$ & $0.374^{\mathrm{b}} \pm 0.005$ \\
10 weeks & $38.17^{\mathrm{a}} \pm 0.052$ & $36.81^{\mathrm{a}} \pm 0.110$ & $0.039^{\mathrm{b}} \pm 0.001$ & $0.073^{\mathrm{b}} \pm 0.001$ & $0.652^{\mathrm{a}} \pm 0.002$ \\
11 weeks & $38.22^{\mathrm{a}} \pm 0.081$ & $37.02^{\mathrm{a}} \pm 0.102$ & $0.028^{\mathrm{b}} \pm 0.001$ & $0.035^{\mathrm{b}} \pm 0.001$ & $0.728^{\mathrm{a}} \pm 0.004$
\end{tabular}

Note: In the same data column, values with similar letters represent non-significant differences, values with different letters represent significant differences $(\mathrm{P} \leq 0.6)$ according to the Tukey test.

Table 2. Content of reducing sugar, starch, total organic acid, vitamin $\mathrm{C}$ in litchi fruit

\begin{tabular}{ccccc}
\hline Age of fruit & $\begin{array}{c}\text { Reducing sugar content } \\
\text { (\% fresh weight) }\end{array}$ & $\begin{array}{c}\text { Starch content } \\
\text { (\% fresh weight })\end{array}$ & $\begin{array}{c}\text { Total organic acid content } \\
(\mathrm{mg} / 100 \mathrm{f} \text { fresh weight })\end{array}$ & $\begin{array}{c}\text { Vitamin C content } \\
(\mathrm{mg} / 100 \mathrm{f} \text { fresh weight })\end{array}$ \\
\hline 2 weeks & $2.138^{\mathrm{e}} \pm 0.034$ & $0.524^{\mathrm{c}} \pm 0.015$ & $48.598^{\mathrm{e}} \pm 0.412$ & $14.652^{\mathrm{f}} \pm 0.105$ \\
4 weeks & $2.457^{\mathrm{e}} \pm 0.018$ & $0.864^{\mathrm{b}} \pm 0.037$ & $56.148^{\mathrm{d}} \pm 0.731$ & $20.238^{\mathrm{e}} \pm 0.290$ \\
6 weeks & $3.369^{\mathrm{d}} \pm 0.062$ & $0.910^{\mathrm{b}} \pm 0.012$ & $65.252^{\mathrm{b}} \pm 0.925$ & $26.135^{\mathrm{d}} \pm 0.531$ \\
8 weeks & $5.756^{\mathrm{c}} \pm 0.042$ & $1.304^{\mathrm{a}} \pm 0.026$ & $72.685^{\mathrm{b}} \pm 0.112$ & $33.917^{\mathrm{c}} \pm 0.384$ \\
9 weeks & $8.753^{\mathrm{b}} \pm 0.065$ & $1.275^{\mathrm{a}} \pm 0.009$ & $77.509^{\mathrm{a}} \pm 0.268$ & $40.353^{\mathrm{b}} \pm 0.118$ \\
10 weeks & $14.237^{\mathrm{a}} \pm 0.093$ & $0.736^{\mathrm{b}} \pm 0.007$ & $68.751^{\mathrm{b}} \pm 0.612$ & $58.667^{\mathrm{a}} \pm 0.235$ \\
11 weeks & $13.907^{\mathrm{a}} \pm 0.126$ & $0.428^{\mathrm{c}} \pm 0.011$ & $60.130^{\mathrm{c}} \pm 0.836$ & $55.083^{\mathrm{a}} \pm 0.478$ \\
\hline
\end{tabular}

Note: In the same data column, values with similar letters represent non-significant differences, values with different letters represent significant differences $(\mathrm{P} \leq 0.6))$ according to the Tukey test. 
Table 3. Content of protein and lipid in litchi fruit

\begin{tabular}{ccc}
\hline Age of fruit & $\begin{array}{c}\text { Protein content } \\
(\% \text { dry weight })\end{array}$ & $\begin{array}{c}\text { Lipid content } \\
(\% \text { dry weight })\end{array}$ \\
\hline 2 weeks & $7.238^{\mathrm{a}} \pm 0.053$ & $3.652^{\mathrm{c}} \pm 0.076$ \\
4 weeks & $7.106^{\mathrm{a}} \pm 0.022$ & $4.423^{\mathrm{b}} \pm 0.020$ \\
6 weeks & $5.325^{\mathrm{b}} \pm 0.016$ & $5.270^{\mathrm{a}} \pm 0.015$ \\
8 weeks & $4.347^{\mathrm{c}} \pm 0.012$ & $5.537^{\mathrm{a}} \pm 0.010$ \\
9 weeks & $4.058^{\mathrm{c}} \pm 0.041$ & $3.130^{\mathrm{c}} \pm 0.006$ \\
10 weeks & $3.719^{\mathrm{d}} \pm 0.028$ & $3.347^{\mathrm{c}} \pm 0.008$ \\
11 weeks & $3.574^{\mathrm{d}} \pm 0.036$ & $3.107^{\mathrm{c}} \pm 0.012$
\end{tabular}

Note: In the same data column, values with similar letters represent non-significant differences, values with different letters represent significant differences( $\mathrm{P} \leq$ $0.6)$ ) according to the Tukey test.

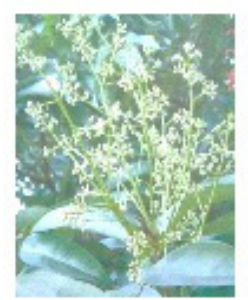

Flowering stage

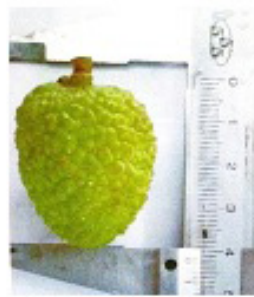

8 weeks

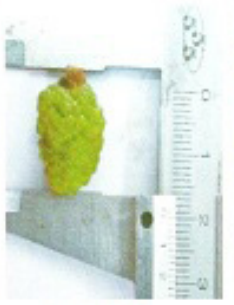

2 weeks

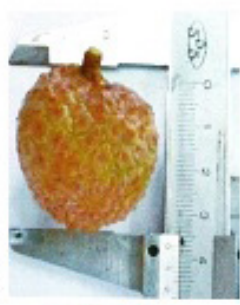

9 weeks

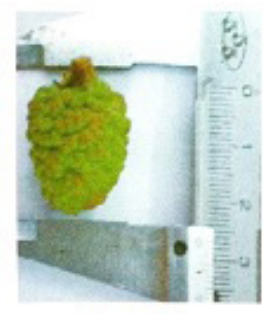

4 weeks

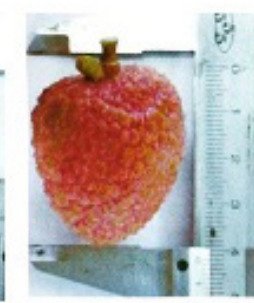

10 weeks

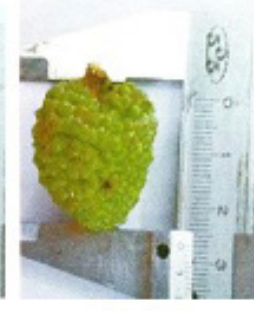

6 weeks

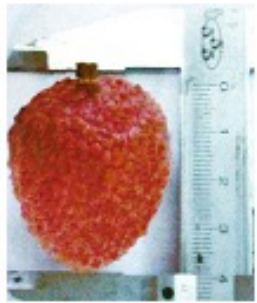

11 weeks

Figure 1. Growth and development of litchi fruit from 2 weeks after anthesis

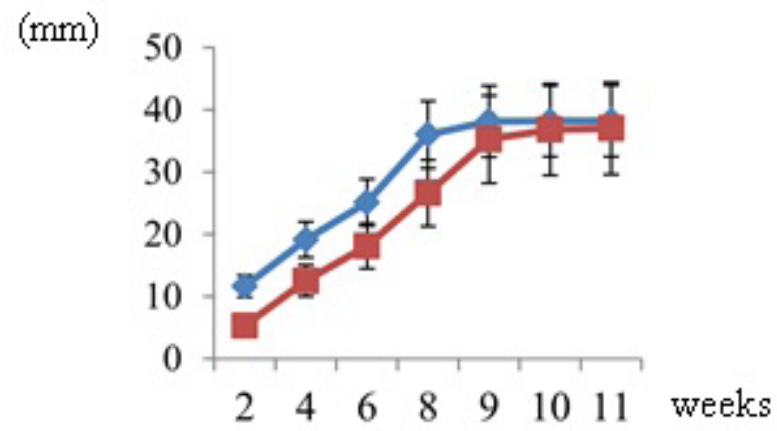

(A)

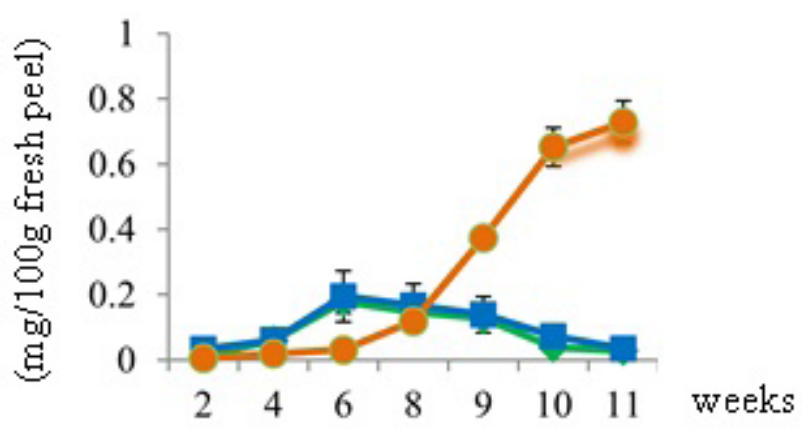

(B)

Figure 2. Changes in length and diameter (A), chlorophyll and carotenoid contents (B) during the growth and development of litchi fruit from 2 weeks after anthesis 


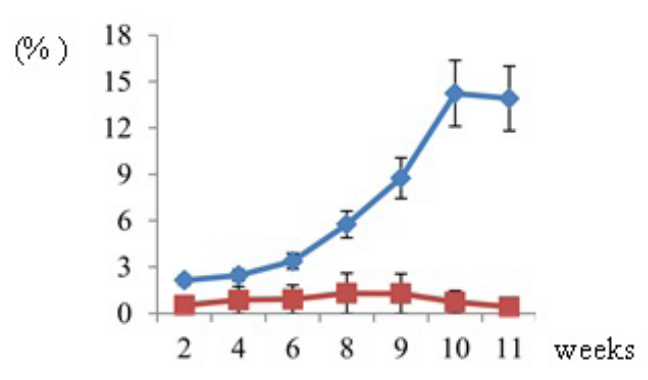

(A)

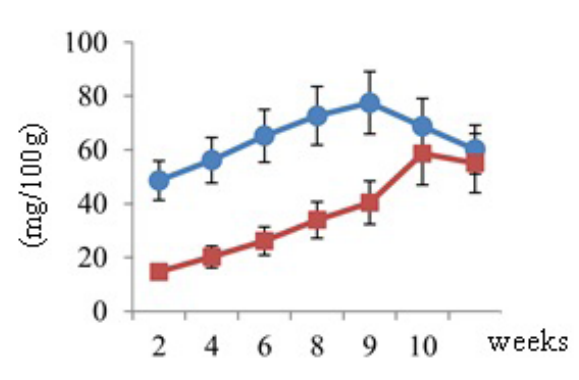

(B)

Figure 3 .Changes in reducing sugar and starch contents (A), total organic acid and vitamin C contents (B) during the growth and development of litchi fruit from 2 weeks after anthesis

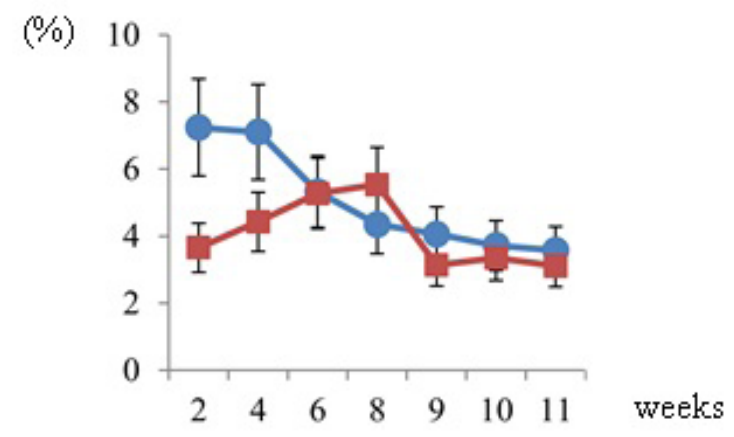

Figure 4. Changes in protein and lipid contents during the growth and development of litchi fruit from 2 weeks after anthesis

\section{Conclusion}

We found that litchi fruit reached physiological maturity at 10 weeks after anthesis, and at this time litchi fruit had a maximum value of reducing sugar, vitamin $\mathrm{C}$ and high content of ingredients such as organic acid, lipid. After 10 weeks most of the main components of the fruit decreased. Therefore, this is the most appropriate time to harvest litchi fruit. If the fruit is harvested earlier or later, its quality will be significantly reduced.

\section{References}

ABU-BAKR, A.G.; ADIL, E.S.; ELFATIH, M.M. Physicochemical changes during growth and development of papaya fruit. I: Physical changes. Agriculture and Biology Journal of North America, Milford, v.1, n.5, p.866-870, 2010.

ARYA, S.P.; MAHAJAN, M.; JAIN, P. Nonspectrophotometric methods for the determination of Vitamin C. Analytica Chimica Acta, Amsterdam, v.417, n. 1, 1-14, 2000.
CHAROENCHONGSUK, N.; IKEDA, K.; ITAI, A.; OIKAWA, A.; MURAYAMA, H. Comparison of the expression of chlorophyll-degradation-related genes during ripening between stay-green and yellow-pear cultivars. Scientia Horticulturae, New York, v.181, p.8994, 2015.

CHAU, P.T.T.; HIEN, N.N., TUONG, P.G. Biochemistry practice. Delhi: Educational Publishing House, 1998. 132p.

CRONJE, R.B. Effect of fruit development, maturity and harvesting of litchi (Litchi chinensis Sonn.) on postharvest fruit quality. Stewart Postharvest Review, London, v.4, p.1-10, 2008.

DU, L.; YANG, X.; SONG, J.; MA, Z.; ZHANG, Z.; PANG, $X$. Characterization of the stage dependency of high temperature on green ripening reveals a distinct chlorophyll degradation regulation in banana fruit. Scientia Horticulturae, New York, v.180, p.139146, 2014. 
EVELLYN, C.O.R.; PAULA, F.M.; RICARDO, A.A.; ANGELO, P.J.; ILANA, U.B. Oxidative processes during "Golden" papaya fruit ripening. Brazilian Journal of Plant Physiology, Campinas, v.24, n.2, 85-94, 2012.

HUANG, X.M.; SUBHADRABANDHU, S.; MITRA, S.K.; BEN-ARIE, R.; STERN, R.A. Origin, history, production and processing. In: MENZEL, C.M.; WAITE, G.H. (ed.). Litchi and longan: botany, production and uses. Wellingford: CAB International, 2005. p.1-23.

JIANG, Y.M.; WANG, Y.; SONG, L.; LIU, H.; LICHTER, A.; KERDCHOECHUEN, O.; JOYCE, D.C.; SHI, J. Postharvest characteristics and handling of litchi fruit - an overview. Australian Journal of Experimental Agriculture, Melbourne, v.46, n.12, 1541-1556, 2006.

LAI, B.; HU, B.; QIN, Y.H. Transcriptomic analysis of Litchi chinensis pericarp during matu-ration with a focus on chlorophyll degradation and flavonoid biosynthesis. BMC Genomics, London, v.16, n.225, 2015.

MA, N.V.; HONG, L.V.; PHONG, O.X. Methods in plant physiology. Hanoi: Hanoi National University Publishing House, 2013. 223p.

MARBOH, E.S.; SANJAY, K.S.; SWAPNIL, P.; VISHAL, N.; GUPTA, A.K.; PONGENER, A. Fruit cracking in litchi (Litchi chinensis): An overview. Indian Journal of Agricultural Sciences, New Delhi, v.87, p.3-11, 2017.

MENZEL, C.M.; SIMPSON, D.R. Effect of temperature on growth and flowering in litchi (Litchi chinensis Sonn.) cultivars. Journal of Horticultural Science, Ashford, v.63, n.2, p.349-360, 1988.

MENZEL, C.M. Fruits of tropical climates: fruits of the Sapindaceae. In: CABALLERO, B.; FINGLAS, P.; TRUGO, L. (ed.). Encyclopedia of food sciences and nutrition. $2^{\text {nd }}$ ed. Oxford: Academic Press, 2003. p.27862790 .

MUI, N.V. Practice in biochemistry. $2^{\text {nd }}$ ed. Hanoi: Technology and Science Publishing House, 2001. 205p.

PATEL, P.R.; GOL, N.B.; RAO, T.V.R.; Physiochemical changes in sunberry (Physalis minima L.) fruit during growth and ripening. Fruits, Paris, v.66, n.1, p.37-46, 2011.
PRASANNA, V.; PRABHA, T.N.; THARANATHAN, R.N. Fruit ripening phenomena-an overview. Critical Reviews in Food Science and Nutrition, Boca Raton, v.47, n.1, p.1-19, 2017.

SINGH, A.; PANDEY, S.D.; VISHAL, N. The World litchi cultivars. Muzaffarpur: NRC for Litchi, Mushahari, 2012. p.1-65. (Technical Bulletin, 7)

VALLARINO, J.G.; OSORIO, S. Organic acids. In: YAHIA, E.M. (ed.). Postharvest physiology and biochemistry of fruits and vegetables. Amsterdam: Elsevier, 2019. p.207-224.

WANG, H.C.; HUANG, X.M.; HU, G.B.; YANG, Z.; HUANG, H.B. A comparative study of chlorophyll loss and its related mechanism during fruit maturation in the pericarp of fast- and slow-degreening litchi pericarp. Scientia Horticulturae, New York, v.106, p.247-257, 2005.

WANG, H.C.; HUANG, H.B.; HUANG, X.M.; HU, Z.Q. Sugar and acid compositions in the arils of Litchi chinensis Sonn. cultivar differences and evidence for the absence of succinic acid. Journal Horticultural Science Biotechnology, Ahsford, v.81, n.1, p.57-62, 2006.

WANG, Y.; LU, W.J.; LI, J.G.; JIANG, Y.M. Differential expression of two expansin genes in developing fruit of cracking-susceptible and -resistant litchi cultivars. Journal of the American Society of Horticultural Science, Alexandria, v.131, p.118-121, 2006.

WILLS, R.H.; MCGLASSON, B.; GRAHAM, D; JOYCE, D. Postharvest: an introduction to the physiology and handling of fruit, vegetables and ornamentals. $4^{\text {thed. }}$ Wellington: CAB International, 1998. 262 p.

YANG, Z.Y.; WANG, T.D.; WANG, H.C.; HUANG, X.M.; QIN, Y.H.; HU, G.B. Patterns of enzyme activities and gene expressions in sucrose metabolism in relation to sugar accumulation and composition in the aril of Litchi chinensis Sonn. Journal Plant Physiology, Stuttgart, v.170, p.731-740, 2013.

YASHODA, H.M.; PRABHA, T.N.; THARANATHAN, R.N. Mango ripening: changes in cell wall constituents in relation to textural softening. Journal of the Science of Food and Agriculture, London, v.86, n.5, p.713-721, 2005. 